\title{
Podatkowe i niepodatkowe obciążenia i ich wpływ na funkcjonowanie przedsiębiorstw
}

\begin{abstract}
Tax and non-tax burdens and their impact on the functioning of enterprises: The article focuses on the corporate fiscal burdens in Poland. The authors discuss the taxes (on income, sales, property, as well as flat-rate taxation forms) and para-taxes (social and health insurance premiums) which in short- and long-term affect entrepreneurial decisions. The analysis pinpoints the structural elements of taxes which enable various tax strategies. On the basis of the empirical data collected the authors determine as well the average amount of income tax, the scale of use of stimulus instruments, the level of impact of the discussed burdens on the financial results of enterprises, and costs related to property taxes and social insurance.
\end{abstract}

Słowa kluczowe: podatkowe i niepodatkowe obciążenia, podatek dochodowy od osób fizycznych, podatek dochodowy od osób prawnych, VAT, podatki majątkowe

Keywords: tax and non-tax burdens, personal income tax, corporate income tax, VAT, property taxes

* Doktor hab. nauk ekonomicznych, profesor SCH, Instytut Finansów • e-mail: pfelis@sgh.waw.pl•https://orcid.org/oooo-0002-2072-7245

** Doktorant w Kolegium Zarządzania i Finansów SGH • e-mail: grzegorz.otczyk@ doktorant.sgh.waw.pl• https://orcid.org/0000-0002-2431-4309

\section{Wstęp}

Działalność przedsiębiorstw jest obciążona podatkami i parapodatkami, przy czym pewne z nich stanowią bezpośredni element podziału akumulacji pieniężnej (podatek od towarów i usług), inne odnoszą się do dochodów (podatek dochodowy), inne jeszcze obciążają koszty działalności przedsiębiorstwa (podatek od nieruchomości, podatek od środków transportu). Podatek dochodowy i VAT dotyczą prawie wszystkich przedsiębiorstw, natomiast obciążenie pozostałymi uzależnione jest m.in. od charakteru i rodzaju prowadzonej działalności oraz 
zasobów majątkowych przedsiębiorstw. Wśród obciążeń niepodatkowych należy wyróżnić przede wszystkim obciążenia związane z kosztami wynagrodzeń (składki na ubezpieczenia społeczne i zdrowotne, na Fundusz Pracy). Podatki, jako jedne z podstawowych narzędzi systemu finansowego, oznaczają regulację środków finansowych pozostających w dyspozycji przedsiębiorstw. Ich zapłacenie powoduje zmniejszenie dochodów przedsiębiorców, co ogranicza możliwości w zakresie inwestowania, oszczędzania i konsumpcji. Ponadto za pomocą określonych rozwiązań podatkowych można również determinować decyzje przedsiębiorców, np. o podjęciu określonej działalności gospodarczej, rozszerzeniu lub ograniczeniu jej zakresu.

Przedmiotem artykułu są zatem kluczowe dla przedsiębiorstw narzędzia podatkowe i niepodatkowe. Zwrócono uwagę na ich oddziaływanie na wysokość obciążeń finansowych. Dlatego ocena skuteczności analizowanych instrumentów została dokonana z punktu widzenia przedsiębiorców. Punktem wyjścia do rozważań jest przedstawienie podatków i parapodatków ${ }^{1}$ mających istotny wpływ na podejmowane w przedsiębiorstwach decyzje bieżące i długofalowe (np. w zakresie płynności, rentowności, finansowania działalności gospodarczej, przedsięwzięć inwestycyjnych). Następnie zbadane zostały wybrane elementy konstrukcyjne, dzięki którym możliwe jest stosowanie strategii powodujących optymalizację obciążeń podatkowych. W formułowaniu części ocen i wniosków posłużono się danymi empirycznymi Głównego Urzędu Statystycznego i Ministerstwa Finansów z lat 2010-2017.

$\mathrm{Na}$ etapie zbierania danych statystycznych napotkano jednak problemy. Przede wszystkim wraz z kolejnymi rocznikami udostępnianymi na stronach Ministerstwa Finansów spadła szczegółowość zestawień. To spowodowało istotne zawężenie danych panelowych, które można było wykorzystać do analizy sytuacji przedsiębiorstw niefinansowych. Innym utrudnieniem był brak wyszczególnienia podmiotów prowadzących działalność gospodarczą i rozliczających się na zasadach ogólnych według skali podatkowej podatku od osób fizycznych (18\% i 32\%). Zabrakło także szczegółowych informacji o przedsiębiorstwach niefinansowych zatrudniających mniej niż 10 osób pracujących. Zwiększająca się liczba tych podmiotów wymaga jednak wyszczególnienia stosownych danych statystycznych do przyszłych analiz dotyczących ich funkcjonowania.

W artykule wykorzystano metodę analizy aktów prawnych z punktu widzenia skutków ekonomiczno-finansowych ich stosowania, a także metodę ogólnej analizy statystycznej danych finansowych.

1 Szerzej zob. P. Felis, M. Jamroży, J. Szlęzak-Matusewicz, Podatki i składki w działalności przedsiębiorców, Difin, Warszawa 2019. 


\section{Obciążenia przedsiębiorstw z tytułu podatków dochodowych}

\section{Opodatkowanie dochodu z działalności gospodarczej}

Problem opodatkowania dochodów generowanych z działalności gospodarczej nabiera szczególnej wagi z wielu powodów. Dotyczy bowiem opodatkowania dochodu wysokiego ryzyka, ogranicza akumulację kapitału i osłabia tempo wzrostu gospodarczego ${ }^{2}$. Takie kategorie jak zakres podstawy opodatkowania, wielość i wysokość stawek podatkowych decydują o tym, na ile podatek zniekształca mechanizm rynkowy i ogranicza aktywność ekonomiczną ${ }^{3}$. Istotne jest tu podejście władzy publicznej, która może dążyć do neutralizacji wpływu podatków na decyzje przedsiębiorstw bądź też przeciwnie - wykorzystując stymulacyjną funkcję podatków - stosować podatkowe instrumenty wspierania rozwoju przedsiębiorców, pobudzając tym samym ich oczekiwane zachowania. Wpływ czynnika podatkowego na decyzje dotyczące transgranicznych przepływów kapitału, zachowania w sferze inwestycji, czy decyzje finansowe nie jest zatem bez znaczenia. Podatki dochodowe wyznaczają zakres samofinansowania przedsiębiorstw, bowiem przez obciążenie zysku brutto określają wynik finansowy netto pozostający do ich dyspozycji. Dlatego też istotnymi elementami konstrukcyjnymi podatków dochodowych, wpływającymi na tę metodę finansowania działalności, są: rodzaj i wysokość taryfy podatkowej, ulgi i zwolnienia oraz inne rozwiązania umożliwiające przedsiębiorcom dzielenie ryzyka rozwojowego z budżetem.

Opodatkowanie dochodów rozpatrywane w wąskim ujęciu ${ }^{4}$ to przede wszystkim: podatek dochodowy od osób prawnych ${ }^{5}$ (CIT), podatek dochodowy od osób fizycznych ${ }^{6}$ (PIT) oraz ich formy zryczałtowane ${ }^{7}$. Ustalenie, będącego

${ }^{2}$ F. Grądalski, Teoretyczne aspekty racjonalizacji systemu podatkowego [w:] Dorobek ekonomii, finansów i nauk o zarządzaniu oraz jego praktyczne wykorzystanie na przełomie XX $i$ XXI wieku, red. R. Bartkowiak, J. Ostaszewski, Oficyna Wydawnicza SGH, Warszawa 2012, s. 577.

3 A. Flotyńska, Alternatywne konstrukcje podatku od dochodów przedsiębiorstw, „Prace Naukowe Uniwersytetu Ekonomicznego we Wrocławiu” 2011, nr 172, s. 546 [Finanse - nowe wyzwania teorii i praktyki. Finanse przedsiębiorstw, red. S. Wrzosek].

${ }^{4}$ Model opodatkowania dochodów może być jednak przedstawiany i analizowany w szerokim ujęciu. Więcej zob. J. Kulicki, Reforma opodatkowania dochodów [w:] Dylematy reformy systemu podatkowego w Polsce, red. H. Dzwonkowski, J. Kulicki, Wydawnictwo Sejmowe, Warszawa 2016, s. 328-329; P. Felis, Ocena funkcjonowania podatków od dochodów osób fizycznych oraz osób prawnych w Polsce, „Studia BAS” 2018, nr 2(54), s. 11-13 [Wybrane zagadnienia reformy opodatkowania dochodów osób fizycznych i prawnych w Polsce, red. J. Kulicki].

5 Ustawa z 15 lutego 1992 r. o podatku dochodowym od osób prawnych, t.j. Dz.U. 2018, poz. 1036, ze zm.

${ }^{6}$ Ustawa z 26 lipca 1991 r. o podatku dochodowym od osób fizycznych, t.j. Dz.U. 2018, poz. 1509 , ze zm.

7 Ograniczono się do ustawy z 20 listopada 1998 r. o zryczałtowanym podatku dochodowym od niektórych przychodów osiąganych przez osoby fizyczne, t.j. Dz.U. 2019, poz. 43. 
funkcją uzyskanych przychodów i poniesionych kosztów, dochodu podatkowego osoby prawnej lub fizycznej wiąże się z różnorakimi obowiązkami w zakresie rachunkowości finansowo-podatkowej. Różnice w zasadach prawa bilansowego i podatkowego powodują jednak odmienne traktowanie dla celów rachunkowych i podatkowych przychodów i kosztów. Różnice te, ze względu na wpływ na wielkość dochodu, mogą być dodatnie lub ujemne $e^{8}$. W literaturze słusznie zwraca się uwagę na fakt, że dla celów podatkowych oderwanie rozpoznawania przychodów oraz kosztów od ujęcia rachunkowego powoduje nadmierną kazuistykę przepisów podatkowych, potęgując spory interpretacyjne ${ }^{9}$. Oceniając poziom opodatkowania, należy brać pod uwagę zarówno zakres podstawy opodatkowania, jak i wysokość stawek podatku. Ogólnym trendem w podatkach dochodowych, począwszy od lat 90. ubiegłego wieku, było obniżanie wysokości nominalnych stawek przy rozszerzaniu ich podstaw (bazy opodatkowania).

W podatku CIT stawka ma charakter proporcjonalny i obecnie wynosi $19 \%$ podstawy opodatkowania (względnie jest obniżona do $9 \%$ dla małych podatników ${ }^{10}$ ). Nie można jednak pomijać opodatkowania na poziomie wspólników, czyli z tytułu otrzymanej dywidendy. Dywidendy podlegają opodatkowaniu w sposób uproszczony, bez uwzględniania kosztów, w wysokości 19\% uzyskanego przychodu. W efekcie ma miejsce podwójne, w sensie ekonomicznym, opodatkowanie dochodów osiągniętych przez osoby prawne. Całkowite obciążenie podatkowe wynosi więc $34,39 \%$ (względnie $26,29 \%$ dla małych podatników) ${ }^{11}$.

W podatku PIT (dochód osiągnięty z tytułu jednoosobowej działalności gospodarczej; dochód osiągnięty z tytułu udziału w spółce osobowej, innej niż spółka komandytowo-akcyjna) dochód podlega opodatkowaniu według progresywnej skali podatkowej $(18 \%, 32 \%)$ lub po spełnieniu przez podatnika określonych warunków ustawowych - według stawki 19\% (określanym potocznie jako podatek liniowy). W przypadku progresji szczeblowanej istotne są także: liczba progów podatkowych (w momencie wprowadzenia PIT zastosowanie znalazła progresja z trzema progami podatkowymi; od 2009 r. liczba progów zmalała do

${ }^{8}$ Zob. I. Olchowicz, M. Jamroży, Rachunkowość podatkowa. Analiza w zakresie podatku dochodowego od osób prawnych, Difin, Warszawa 2018.

${ }^{9}$ M. Jamroży, Dochody $z$ działalności gospodarczej - analiza stanu obecnego i możliwe kierunki zmian, „Studia BAS” 2018, nr 2(54), s. 200 [Wybrane zagadnienia reformy opodatkowania dochodów osób fizycznych i prawnych w Polsce, red. J. Kulicki].

${ }^{10}$ Kryterium klasyfikacji podatników jest oparte na przychodach ze sprzedaży. Wartość przychodu ze sprzedaży (wraz z kwotą VAT) małych podatników nie przekroczyła w poprzednim roku podatkowym 1,2 mln euro (od 2020 r. -2 mln euro).

${ }_{11}$ W sytuacji udziałowców w formie spółek kapitałowych przychód uzyskany z tytułu otrzymania dywidendy będzie jednak (w wypadku spełnienia określonych przez ustawodawcę warunków, np. co do wysokości i czasu posiadania udziałów) zwolniony od podatku. Wówczas wyeliminowane zostaje na poziomie udziałowca będącego osobą prawną podwójne, w sensie ekonomicznym, opodatkowanie. 
dwóch); kwoty dla poszczególnych progów podatkowych (od 2009 r. jest to kwota 85528 zł), kwota tzw. ustawowej obniżki podatku, która wpływa na wysokość kwoty wolnej od podatku (do końca 2016 r. kwota 556,02 zł, później zmienna, uzależniona od wysokości podstawy obliczenia podatku, ale dla większości podatników w dalszym ciągu ta sama kwota); waloryzacja bądź jej brak progów podatkowych, kwoty wolnej od opodatkowania (w przeszłości ustawodawca nie zawsze stosował rozwiązania mające uchronić podatników przed wzrostem obciążeń fiskalnych pod wpływem inflacji - zjawisko tzw. zimnej progresji).

Intencją wprowadzenia przez ustawodawcę od 2004 r. stawki liniowej dla podmiotów prowadzących działalność gospodarczą w formach osobowych było na gruncie podatku dochodowego zrównanie warunków funkcjonowania przedsiębiorstw w różnych formach prawnych. Przy czym, jak podkreśla się w literaturze, ujednolicenie stawek w obydwu podatkach dochodowych, bez zniesienia podwójnego opodatkowania zysku wydzielonego, nie zrównuje jednak opodatkowania dochodów przeznaczonych na własne potrzeby właścicieli przedsiębiorst $\mathrm{w}^{12}$. W kontekście analizowanego zagadnienia skonstatować trzeba, iż będący osobą fizyczną wspólnik spółki kapitałowej jest pod względem podatkowym traktowany mniej korzystnie niż wspólnik spółki niebędącej osobą prawną ${ }^{13}$. Jego obciążenie podatkowe jest bowiem wyższe o 15,39 (względnie $7,29)$ punktów procentowych.

Stawki w podatkach dochodowych, jak stwierdzono, od lat utrzymują się na tym samym poziomie (z wyjątkiem preferencyjnej stawki CIT). Dlatego uznano, że obecnie to sposób określenia podstawy opodatkowania jest spośród wielu aspektów podatków dochodowych jednym z wywierających największy wpływ na rozwój przedsiębiorstw. W polskich przepisach ustaw o podatkach dochodowych do instrumentów wspierania rozwoju przedsiębiorstw na szczególną uwagę zasługują: niektóre rozwiązania w zakresie amortyzacji podatkowej (strategia kosztowa, a także jako możliwość dzielenia przez przedsiębiorstwo ryzyka rozwojowego z budżetem); ulga badawczo-rozwojowa (strategia dochodowa); rozliczanie strat podatkowych (możliwość dzielenia przez przedsiębiorstwo ryzyka rozwojowego z budżetem).

Zasadniczą częścią systemu kształtującego podstawę opodatkowania podatkiem dochodowym przedsiębiorstw jest system podatkowy amortyzacji. Słusznie się podkreśla w literaturze, że jego waga jest szczególnie istotna, ponieważ dotyczy długotrwałych procesów w przedsiębiorstwie, wynikających $\mathrm{z}$ działalności inwestycyjnej ${ }^{14}$. Oceniając system podatkowy amortyzacji, należy przede wszystkim zwrócić uwagę na rozwiązania umożliwiające szybsze

12 M. Kluzek, Charakter podatku dochodowego od osób fizycznych w Polsce [w:] O nowy ład podatkowy w Polsce, red. J. Ostaszewski, Oficyna Wydawnicza SGH, Warszawa 2007, s. 522.

${ }_{13}$ Szerzej M. Jamroży, Dochody z działalności gospodarczej, op. cit., s. 182 i n.

${ }_{14}$ J. Iwin-Garzyńska, System amortyzacji podatkowej w kontekście idei wspólnej skonsolidowanej podstawy opodatkowania, „Prace Naukowe Uniwersytetu Ekonomicznego we 
zaliczenie poniesionych wydatków inwestycyjnych (ceny nabycia względnie kosztu wytworzenia środka trwałego) do kosztów uzyskania przychodów. Jest to możliwe $\mathrm{z}$ reguły przez:

- jednorazowy odpis amortyzacyjny w przypadku niskocennych składników majątkowych, których wartość początkowa nie przekracza $10000 \mathrm{zł}$,

- jednorazowy odpis amortyzacyjny w przypadku małych podatników oraz rozpoczynających działalność, do łącznej wysokości 50000 euro w roku podatkowym, w którym zostały one wprowadzone do ewidencji środków trwałych,

- jednorazowy odpis amortyzacyjny dla fabrycznie nowych środków trwałych w roku podatkowym, w którym zostały one wprowadzone do ewidencji środków trwałych, do wysokości nieprzekraczającej w roku podatkowym 100000 zł, pod warunkiem że wartość nakładów wynosi co najmniej $10000 \mathrm{zł}$,

- zastosowanie metody degresywnej - stawka amortyzacyjna z ustawowego wykazu stawek amortyzacyjnych jest podwyższana o współczynnik nie większy niż 2,0,

- podwyższenie liniowych stawek amortyzacyjnych o współczynnik 1,2; 1,4 lub 2,0 w odniesieniu do budynków i budowli używanych w warunkach pogorszonych albo złych lub też w odniesieniu do maszyn i urządzeń poddanych szybkiemu postępowi technicznemu,

- ustalenie indywidualnych stawek amortyzacyjnych dla używanych lub ulepszonych środków trwałych, z uwzględnieniem określonych w przepisach minimalnych okresów amortyzacji.

Z zaprezentowanego wykazu wynika, że polski system amortyzacji podatkowej stwarza przedsiębiorcom możliwości stosowania przyśpieszonych metod amortyzacji środków trwałych w celu obniżenia podstawy opodatkowania. W wyniku ich wykorzystania podatnik korzysta $\mathrm{z}$ efektu odroczenia opodatkowania, ze względu na szybsze uznanie ceny nabycia (kosztów wytworzenia) za koszty uzyskania przychodów. Tego rodzaju przesunięcia dochodu w czasie powodują więc okresowe różnice $\mathrm{w}$ obciążeniu podatkowym (okresowe oszczędności podatkowe, tzw. podatkowy efekt odsetkowy). Mimo pewnych zalet i pozytywnych $w$ ostatnim czasie zmian przepisów polskie regulacje podatkowe w zakresie amortyzacji - w kontekście ich wsparcia inwestycyjnego nie są oceniane jednoznacznie korzystnie. W literaturze pojawiają się nawet określenia, że są one nadmiernie restrykcyjne ${ }^{15}$.

Wrocławiu" 2011, nr 172, s. 568 [Finanse - nowe wyzwania teorii i praktyki. Finanse przedsiębiorstw, red. S. Wrzosek].

15 M. Jamroży, Podatkowe zachęty inwestycyjne dla przedsiębiorców, „Prace Naukowe Uniwersytetu Ekonomicznego we Wrocławiu" 2011, nr 172, s. 579 [Finanse - nowe wyzwania teorii i praktyki. Finanse przedsiębiorstw, red. S. Wrzosek]. 
Wzrost poziomu techniczno-ekonomicznego produktów oraz unowocześnianie metod ich wytwarzania należą do istotnych czynników warunkujących rozwój przedsiębiorstw. Niezbędne są więc prace badawczo-rozwojowe ${ }^{16}$, które łączą się z ponoszeniem określonych (niemałych zazwyczaj) wydatków. Niski wskaźnik nakładów na działalność badawczo-rozwojową w stosunku do $\mathrm{PKB}^{17}$, mało pozytywne opinie na temat innowacyjności polskiej gospodarki, nieskuteczne wcześniej funkcjonujące instrumenty podatkowe (np. ulga na nowe technologie ${ }^{18}$ ) zapewne stanowily impuls dla ustawodawcy do podjęcia działań i przyjęcia od 2016 r. nowego rozwiązania - ulgi na badania i rozwój $(\mathrm{B}+\mathrm{R})$. Z tej preferencji podatkowej mogą skorzystać podatnicy CIT i PIT (także opłacający podatek dochodowy przy zastosowaniu proporcjonalnej skali podatkowej). Jej istota polega na możliwości odliczenia kosztów poniesionych na działalność $\mathrm{B}+\mathrm{R}$ (tzw. kosztów kwalifikowanych, np. kosztów wynagrodzeń; nabycia materiałów, surowców, sprzętu specjalistycznego; ekspertyz, opinii; odpłatnego korzystania $\mathrm{z}$ aparatury naukowo-badawczej) od podstawy opodatkowania.

Podatkowa korzyść przedsiębiorcy podejmującego działalność innowacyjną polega więc na dwukrotnym uwzględnieniu tych samych wydatków przy obliczaniu podstawy opodatkowania. Podatnicy poza zaliczeniem takich wydatków do kosztów uzyskania przychodów mają bowiem możliwość skorzystania $\mathrm{z}$ dodatkowego odliczenia tych kosztów od podstawy opodatkowania (maksymalna wysokość kosztów kwalifikowanych podlegających odliczeniu wynosi zasadniczo $100 \%$, a w przypadku podatników posiadających status centrum badawczo-rozwojowego - 150\%). Warto podkreślić, że uprawnienie do korzystania z rzeczonej ulgi podatkowej nie zależy ani od poziomu innowacyjności przedsiębiorcy, ani od ostatecznych rezultatów podjętych przez niego prac badawczo-rozwojowych. Mankamentem jest zaś dyskryminacja podatników osiągających dochody z działalności gospodarczej i opłacających podatek dochodowy w formie ryczałtu od przychodów ewidencjonowanych. Wybór formy opodatkowania dochodów z działalności gospodarczej nie przesądza przecież o zakresie jej innowacyjności.

${ }^{16}$ Interesujący przegląd podatkowych rozwiązań wsparcia działalności badawczo-rozwojowej przedsiębiorstw w krajach europejskich zob. m.in. J. Szlęzak-Matusewicz, Models of Tax Incentives for R\&D Activities of Enterprises in European Union Countries, „Copernican Journal of Finance \& Accounting” 2014, vol. 3, nr 1, s. 145-160, http://dx.doi.org/10.12775/ CJFA.2014.012

17 W Polsce intensywność prac B+R, czyli udział nakładów wewnętrznych na badania i prace rozwojowe w PKB w latach 2012-2016 stanowił średnio zaledwie ok. 0,93\%. W $2017 \mathrm{r}$. wskaźnik wzrósł do 1,03\%.

${ }_{18}$ Szerzej na temat tej preferencji zob. N. Kotlarek, Ulga z tytułu nowych technologii mankamenty konstrukcji i propozycje modyfikacji, „Annales Universitatis Mariae Curie-Skłodowska, Sectio H Oeconomia” 2016, vol. L, nr 1. 
Dzięki możliwości rozliczania strat podatkowych w czasie (od 2 do 5 lat) ${ }^{19}$ poprzez uwzględnienie ich $w$ podstawie opodatkowania dochodzi do przejęcia części ryzyka związanego z działalnością przedsiębiorstwa przez budżet państwa. Uzupełnieniem tego rozwiązania jest nowa, alternatywna metoda, mająca jednak zastosowanie dopiero do straty powstałej po 31 grudnia 2018 r. Przedsiębiorcy będą mogli odliczyć nawet całą wartość poniesionej straty w jednym z najbliższych kolejno po sobie następujących 5 latach podatkowych, pod warunkiem że kwota osiągniętej straty nie przekroczyła $5 \mathrm{mln} \mathrm{zt}^{20}$. Dzięki temu jednorazowemu obniżeniu dochodu do opodatkowania przedsiębiorca ma możliwość niezamrażania środków pieniężnych. Decyzja o wyborze okresu zależy nie tylko od wysokości dochodu pozwalającego na odliczenie straty, ale także kalkulacji, kiedy pomniejszenie dochodu będzie pomocne, a może nawet bardziej odczuwalne. Rozwiązanie niewątpliwie wzbogaca obszar zarządzania stratami podatkowymi przez podatnika.

Funkcjonowanie przedsiębiorstwa wymaga finansowania majątku niezbędnego do prowadzenia działalności bieżącej i rozwoju przedsiębiorstwa. Potrzeby finansowe mogą być zaspokajane z poszczególnych źródeł - wewnętrznych i zewnętrznych. Ich opodatkowanie jest w obecnym stanie prawnym zróżnicowane. Dlatego też w procesie podejmowania decyzji finansowych przedsiębiorcy nie powinni pomijać skutków podatkowych. Ponieważ pewne konsekwencje podatkowe w przypadku finansowania wewnętrznego zostały zarysowane (m.in. amortyzacja podatkowa), wskażmy na wybrane skutki dotyczące finansowania zewnętrznego (kredyt bankowy, pożyczka od wspólnika, leasing).

Korzyści wynikające ze zmniejszenia obciążenia podatkowego przedsiębiorcy w związku z zaliczeniem odsetek od kapitału obcego do kosztów uzyskania przychodów określa się jako odsetkową tarczę podatkową. Wydatki w postaci odsetek, prowizji bankowych będą stanowiły koszt podatkowy, jeśli spełnione są określone warunki - pozostają one w związku przyczynowo-skutkowym z przychodami; są faktycznie zapłacone; nie zwiększają kosztów inwestycji w okresie ich realizacji.

Od 2018 r. zaliczenie odsetek do kosztów uzyskania przychodów doznaje również ograniczenia w związku z limitowaniem kosztów finansowania dłużnego ${ }^{21}$. Formuła ograniczeń w zaliczeniu odsetek do kosztów podatkowych

19 Dochód podatkowy można obniżyć o wysokość straty podatkowej w najbliższych, kolejno po sobie następujących 5 latach podatkowych po roku poniesienia straty, w ramach tego samego źródła przychodów. Podatnik sam dokonuje wyboru okresu rozliczenia straty podatkowej, z tym że wysokość obniżenia dochodu nie może przekroczyć w którymkolwiek $\mathrm{z}$ tych lat $50 \%$ kwoty poniesionej straty.

${ }^{20} \mathrm{~W}$ sytuacji straty przekraczającej $5 \mathrm{mln}$ zł podatnik może taką nadwyżkę rozliczyć w którymkolwiek z 5 lat, ale stosując limit 50\% odliczenia w jednym roku.

${ }^{21}$ Koszty finansowania dłużnego odnoszą się do kosztów poniesionych w związku z transakcjami na rzecz podmiotów powiązanych i niepowiązanych oraz obejmują swoim zakresem wszelkiego rodzaju koszty związane z uzyskaniem finansowania. 
oparta jest na zmodyfikowanym dla potrzeb podatkowych wskaźniku EBITDA (earnings before interest, taxes, depreciation and amortization). Podatnicy są zobowiązani wyłączyć $\mathrm{z}$ kosztów podatkowych koszty finansowania dłużnego w części, w jakiej ich nadwyżka przewyższa $30 \%$ podatkowego wskaźnika EBITDA. W celu ustalenia kosztów finansowania dłużnego, które należy wyłączyć z kosztów podatkowych, przedsiębiorca powinien także ustalić, czy nadwyżka poniesionych przez niego kosztów finansowania dłużnego przekracza tzw. próg de minimis, do którego wysokość tej nadwyżki stanowi koszt podatkowy (kwota $3 \mathrm{mln}$ zł). W przypadku umów leasingowych korzystny efekt odsetkowy dla przedsiębiorcy zależy od rodzaju umowy. W wariancie, zakładającym, że przedmiot umowy amortyzuje dla celów podatku dochodowego leasingodawca (finansujący), opłata leasingowa (część kapitałowa i opłata dodatkowa) stanowi w pełnej wysokości koszt uzyskania przychodów. Natomiast w wariancie, gdy przedmiot amortyzuje leasingobiorca (korzystający), kosztem podatkowym są odsetkowa część opłaty leasingowej oraz odpis amortyzacyjny ${ }^{22}$.

Przedsiębiorstwa mogą skorzystać z określonych instrumentów podatkowych pozwalających na przesunięcie w czasie zapłaty podatku, a to wpływa pozytywnie na ich płynność finansową ${ }^{23}$. Do instrumentów takich należą: zaliczki kwartalne, zaliczki uproszczone oraz kredyt podatkowy. W wypadku zaliczek kwartalnych mali podatnicy oraz podatnicy rozpoczynający działalność gospodarczą mają możliwość odroczenia płatności podatku i w konsekwencji tego sposobność zarządzania środkami pieniężnymi. Opłacanie zaliczek w stałej wysokości (tzw. tryb uproszczony) spełni swój cel i spowoduje odsunięcie w czasie momentu zapłaty podatku jedynie w sytuacji dużego wzrostu dochodów w roku wpłacania zaliczek w tej formie w porównaniu $\mathrm{z}$ wcześniejszym okresem ${ }^{24}$. W wyniku stosowania kredytu podatkowego dochodzi natomiast do przesunięcia płatności podatku dochodowego w całości o rok, a następnie częściowo na pięć lat.

\section{Formy zryczałtowane opodatkowania}

Formy zryczałtowane są trwałym elementem systemu opodatkowania podatkami dochodowymi. Zostały one oderwane od dochodowości przedsiębiorstwa. Ich wybór, tak jak i pozostałych (zasady oparte na opodatkowaniu dochodu),

22 Szerzej P. Russel, Leasing [w:] Finansowanie przedsiębiorstwa. Ujęcie teoretyczno-praktyczne, red. J. Szlęzak-Matusewicz, P. Felis, Wolters Kluwer, Warszawa 2014.

${ }^{23}$ Szerzej P. Felis, J. Szlęzak-Matusewicz, Optymalizacja podatkowa a termin płatności podatku [w:] Eseje o finansach, red. J. Ostaszewski, P. Felis, J. Szlęzak-Matusewicz, Oficyna Wydawnicza SGH, Warszawa 2018.

${ }^{24} \mathrm{~W}$ przypadku podatników PIT zaliczki te wpłacane są od dochodu wykazanego w zeznaniu złożonym $\mathrm{w}$ roku podatkowym poprzedzającym dany rok podatkowy (ewentualnie w roku podatkowym poprzedzającym dany rok podatkowy o dwa lata). W przypadku podatników CIT zaś podstawą obliczania zaliczek jest podatek należny wykazany w poprzednich zeznaniach podatkowych. 
zależy od wielu czynników, m.in. rodzaju prowadzonej działalności, jej rozmiaru, wysokości przychodów i kosztów, a także liczby osób zatrudnionych ${ }^{25}$. Zaletą form zryczałtowanych jest przede wszystkim ograniczenie obowiązków sprawozdawczo-księgowych (np. brak obowiązku prowadzenia ksiąg rachunkowych, księgi przychodów i rozchodów, ewidencji środków trwałych oraz wartości niematerialnych i prawnych).

Osoby fizyczne prowadzące samodzielnie działalność gospodarczą albo $\mathrm{w}$ formie spółek cywilnych lub jawnych osób fizycznych mają co do zasady możliwość wyboru opodatkowania w następujących formach zryczałtowanych: karty podatkowej albo ryczałtu od przychodów ewidencjonowanych.

Wysokość ryczałtowego, kwotowego podatku w przypadku karty podatkowej zależy od rodzaju prowadzonej działalności, miejsca jej wykonywania oraz liczby zatrudnionych osób. Ponieważ konstrukcja podatku w formie karty podatkowej nie uwzględnia wyrażonej wartościowo podstawy opodatkowania, przedsiębiorcy nie mogą skorzystać z żadnych ulg pośrednich (np. ulgi badawczo-rozwojowej). Mogą oni jedynie skorzystać z ulg bezpośrednich, czyli obniżek podatku. Nie są to jednak instrumenty o charakterze stymulacyjnym (wspieranie rozwoju przedsiębiorstw). Wymagają ponadto dodatkowych działań ze strony podatnika, ale i dobrej woli pracowników urzędów skarbowych (dotyczy ulg uznaniowych).

Stała kwota podatku ryczałtowego nakładana na przedsiębiorcę niezależnie od jego ekonomicznych efektów działalności teoretycznie może być korzystna (najbardziej przyjazna dla mechanizmu rynkowego oraz z punktu widzenia aktywności gospodarczej $\left.{ }^{26}\right)$. W praktyce jednak, w sytuacji gorszej koniunktury gospodarczej, niezadowalających wyników ekonomicznych (brak dochodów) podatek należy zapłacić. Pewnym rozwiązaniem jest możliwość zgłoszenia przerwania działalności. Rozwiązanie to jest uzasadnione także dla przedsiębiorców, których działalność ma sezonowy charakter. Wówczas podatnik zawieszający działalność gospodarczą nie płaci podatku za okres jej zawieszenia. Na tle innych form opodatkowania działalności gospodarczej, możliwości oddziaływania przedsiębiorców na wysokość ciężaru podatkowego są jednak znikome (nie można stosować ani strategii ukrywania przychodów, ani strategii kosztowej).

25 Szerzej: J. Szlęzak-Matusewicz, Wybrane instrumenty optymalizacji podatkowej w mikroprzedsiębiorstwach - ocena i perspektywy zmian w niniejszym numerze „Studiów BAS”; P. Felis, Opodatkowanie według zasad ogólnych, liniowe czy ryczałtowe - dylematy wyboru matych i średnich przedsiębiorstw [w:] Finanse przedsiębiorstwa, red. P. Karpuś, Wydawnictwo Uniwersytetu Marii Curie-Skłodowskiej, Lublin 2006; P. Felis, Wybrane rozwiąania opodatkowania małych przedsiębiorstw - ocena i proponowane kierunki zmian, „Studia BAS” 2014, nr 1(37) [Rozwój przedsiębiorczości oraz sektora małych i średnich przedsiębiorstw, red. G. Gołębiowski].

${ }^{26}$ F. Grądalski, Teoretyczne aspekty reformowania systemu podatkowego - zarys modelu referencyjnego dla Polski [w:] O nowy ład podatkowy w Polsce, red. J. Ostaszewski, Oficyna Wydawnicza SGH, Warszawa 2007, s. 56. 
W przypadku ryczałtu od przychodów ewidencjonowanych, w zależności od rodzaju pozarolniczej działalności gospodarczej, przychód z niej uzyskiwany opodatkowany jest proporcjonalną stawką $(3 \% ; 5,5 \% ; 8,5 \% ; 17 \%$ oraz 20\%). Z uwagi na fakt, że podatnik płaci podatek od przychodu, w tej formie opodatkowania może zdarzyć się sytuacja, że przedsiębiorca będzie miał ujemny wynik działalności, ale będzie musiał uiścić zryczałtowany podatek. W ryczałcie od przychodów ewidencjonowanych nie uwzględnia się więc kosztów uzyskania przychodów, a proporcjonalne stawki stosuje się do przychodu pomniejszonego o niektóre odliczenia, z których mogą skorzystać podatnicy rozliczający się według zasad ogólnych (m.in. przekazane na wskazane w ustawie cele darowizny, składki na powszechne ubezpieczenia społeczne, wpłaty na indywidualne konta zabezpieczenia emerytalnego (IKZE), wydatki poniesione na użytkowanie internetu, wydatki na cele rehabilitacyjne podatnika z niepełnosprawnością lub członka jego rodziny) i ewentualnie stratę poniesioną w okresie, gdy podatnik był opodatkowany na zasadach ogólnych. W przypadku tego ryczałtu wystarczy jedynie prosta ewidencja przychodów. To ważna zaleta, bowiem dla mikro i małych przedsiębiorstw rozliczenia podatkowe powinny być jak najprostsze, aby nie angażować i tak ograniczonych na ogół ich zasobów finansowych.

Niektórzy ryczałtowcy mają także pewne możliwości optymalizacji podatku w kontekście terminu jego płatności. Chodzi o kwartalne wpłaty podatku przez podatników, których otrzymane przychody z działalności prowadzonej samodzielnie albo przychody spółki (cywilnej lub jawnej osób fizycznych) nie przekroczyły w roku poprzedzającym rok podatkowy kwoty stanowiącej równowartość 25 tys. euro. W literaturze podkreśla się, że katalog korzyści jest jednak skromniejszy niż katalog mankamentów. Do najważniejszych należy zaliczyć: ograniczone możliwości kształtowania podstawy opodatkowania; brak instrumentów wsparcia inwestycyjnego; zbyt wysokie, w relacji do osiąganej rentowności z poszczególnych rodzajów działalności, stawki podatku ${ }^{27}$.

\section{Obciążenia przedsiębiorstw $\mathbf{z}$ tytułu podatków obrotowych ${ }^{28}$}

Przedsiębiorcy biorący udział w obrocie towarami i usługami jako płatnicy podatku od towarów i usług ${ }^{29}$ (VAT) nie powinni ponosić jego ekonomicznych skutków, a jedynie uczestniczyć w procesie jego naliczania. W praktyce jednak

27 J. Ickiewicz, Obciążenia fiskalne przedsiębiorstw, PWE, Warszawa 2009, s. 190-192; P. Felis, Obciążenie pozarolniczej działalności gospodarczej zryczałtowanym podatkiem od przychodów - stan obecny i perspektywy zmian, „Studia i Prace Kolegium Zarządzania i Finansów SGH” 2014, nr 137.

${ }^{28} \mathrm{~W}$ artykule ograniczono się do podatku od towarów i usług, pomijając podatek akcyzowy.

29 Ustawa z 11 marca 2004 r. o podatku od towarów i usług, t.j. Dz.U. 2018, poz. 2174, ze zm. 
VAT oddziałuje na finanse przedsiębiorstw ${ }^{30}$, a skala jego oddziaływania jest uzależniona m.in. od regulacji wymienionych poniżej.

- Warunków odliczenia VAT. Podatnik ma prawo odliczyć kwotę podatku naliczonego od podatku należnego $\mathrm{w}$ zakresie, $\mathrm{w}$ jakim towary i usługi są wykorzystywane do wykonywania czynności opodatkowanych. Co do zasady, podatek naliczony podlega odliczeniu w rozliczeniu za okres, w którym w odniesieniu do nabytych przez podatnika towarów i usług powstał obowiązek podatkowy, jednak nie wcześniej niż w rozliczeniu za okres, w którym podatnik otrzymał fakturę. Nie wszyscy jednak mogą z tego prawa skorzystać. Wyłączenie prawa o charakterze podmiotowym dotyczy np. przedsiębiorców świadczących usługi przewozu osób taksówkami osobowymi (jeśli wybrali opodatkowanie VAT w formie 4\% ryczałtu); przedsiębiorców świadczących usługi turystyczne (u których opodatkowaniu podlega marża). W przypadku nabycia samochodów osobowych oraz innych samochodów o masie całkowitej mniejszej nić 3,5 tony, podatek naliczony wynosi $50 \%$ wartości określonej na fakturze, chyba że są one wykorzystywane wyłącznie do działalności gospodarczej i potwierdza to prowadzona ewidencja przebiegu tych pojazdów. Jeśli natomiast podatnik wykorzystuje towary i usługi nie tylko do czynności, w związku z którymi można obniżyć kwotę podatku należnego, ale i do tych, względem których nie ma takiego prawa - wówczas może on, ustalając współczynnik struktury sprzedaży, skorzystać wyłącznie z częściowego odliczenia podatku naliczonego.

- Terminów i zakresu zwrotu nadwyżki podatku naliczonego nad należnym. Podatnik decyduje, czy chce otrzymać zwrot takiej nadwyżki na rachunek bankowy (zwrot bezpośredni), czy też preferuje jej rozliczenie w przyszłych okresach rozliczeniowych (zwrot pośredni). Kluczowe są terminy zwrotu bezpośredniego. Podstawowy termin wynosi 60 dni od dnia złożenia deklaracji. Termin ten może zostać na umotywowany wniosek podatnika skrócony do $25 \mathrm{dni}$, ale może też ulec wydłużeniu decyzją naczelnika urzędu skarbowego, gdy zostanie zakwestionowana zasadność zwrotu.

- Zwolnień podatkowych. Zwolnienie dotyczy osiągających niewielkie obroty w poprzednim roku podatkowych - tzw. drobnych przedsiębiorców (obrót netto nie może przekroczyć 200 tys. zł) oraz rozpoczynających działalność gospodarczą. Rezygnacja ze zwolnienia jest możliwa pod warunkiem pisemnego zawiadomienia organu podatkowego. Wybór pomiędzy statusem czynnego podatnika VAT a podatnika zwolnionego powinien być poprzedzony analizą opłacalności. Podatnik zwolniony odnosi pewne korzyści formalne - nie musi prowadzić ewidencji podatkowej i wypełniać wielu obowiązków sprawo-

${ }^{30} \mathrm{Z}$ innych kwestii nieporuszonych warto zwrócić uwagę na mechanizm odwrotnego obciążenia. Szerzej zob. J. Szlęzak-Matusewicz, Odwrotne obciążenie VAT jako mechanizm przeciwdziałający oszustwom podatkowym, „Zeszyty Naukowe Uniwersytetu Szczecińskiego. Finanse, Rynki Finansowe, Ubezpieczenia" 2015, t. 1, nr 76, s. 265-276 [Opodatkowanie przedsiębiorstw, red. J. Iwin-Garzyńska]. 
zdawczych. Zwolnienie podmiotowe pozbawia podatnika jednak możliwości obniżenia podatku należnego o podatek naliczony wykazywany w fakturach zakupowych. W takiej sytuacji nieodliczony podatek staje się dla przedsiębiorcy kosztem, co może prowadzić do wzrostu cen sprzedawanych towarów i usług.

- Terminów płacenia podatku. Podatek jest, co do zasady, rozliczany za okresy miesięczne do 25. dnia miesiąca następującego po miesiącu, w którym powstał obowiązek zapłaty podatku. W praktyce najczęściej powstanie obowiązku podatkowego nie wiąże się z faktem otrzymania zapłaty za opodatkowany towar lub usługę. Przedsiębiorstwa zmuszone są zatem zapłacić różnicę między kwotą podatku należnego a naliczonego $\mathrm{z}$ własnych lub pożyczonych środków. Mali podatnicy mogą skorzystać z metody kwartalnej (obowiązek podatkowy powstaje na zasadach ogólnych, ale VAT jest rozliczany nie w okresach miesięcznych, lecz kwartalnych) bądź metody kasowej (co oznacza nie tylko kwartalne rozliczenie podatku, ale również kasowe, czasami quasi-kasowe ujęcie obowiązku podatkowego oraz prawa do odliczenia podatku naliczonego). Czynnikiem decydującym o wprowadzeniu rozwiązań dla małych podatników była chęć poprawy ich sytuacji finansowej. Wybory tej grupy podatników powinna jednak poprzedzać wnikliwa analiza, uwzględniająca specyficzne dla konkretnych przypadków determinanty ${ }^{31}$.

- Wysokości stawek podatkowych. Zastosowanie stawki podstawowej 23\% lub preferencyjnych: $8 \% ; 6,5 \% ; 5 \% ; 4 \%$ oraz $0 \%$ wpływa na cenę, stając się jednym $\mathrm{z}$ wyznaczników popytu.

- Pozostałych, takich jak ulga na złe długi, mechanizm podzielonej płatności. Pierwsze rozwiązanie dotyczy rozliczenia podatku w związku z nieściągalnymi wierzytelnościami. Jej skutkiem jest odciążenie dostawcy w zakresie ponoszenia kosztu podatkowego, w sytuacji gdy odbiorca nie uregulował zobowiązania wynikającego z wystawionej faktury. Przedsiębiorca może bowiem w przypadku wierzytelności, których nieściągalność została uprawdopodobniona (po spełnieniu jeszcze innych warunków), dokonać korekty podstawy opodatkowania i podatku należnego z tytułu dostawy towarów lub świadczenia usług. Istotą drugiego (splitpayment) jest rozdzielenie płatności za nabyty towar lub usługę w taki sposób, że część zapłaty odpowiadająca wartości sprzedaży netto jest płacona przez nabywcę na zwykły rachunek bankowy lub w inny sposób, pozostała zaś część odpowiadająca kwocie podatku VAT - na specjalne konto (tzw. rachunek VAT), którego środkami można dysponować w ograniczony sposób. Podatnik może dokonać przelewu ze swojego rachunku VAT, płacąc VAT wynikający z otrzymanej faktury bądź z deklaracji VAT. Z mechanizmem podzielonej płatności wiążą się określone przywileje, np. szybszy zwrot bezpośredni (dokonywany w terminie $25 \mathrm{dni}$ ), obniżenie zobowiązania VAT w przypadku dokonania zapłaty przed terminem.

\footnotetext{
${ }^{31}$ Szerzej zob. P. Felis, J. Szlęzak-Matusewicz, Optymalizacja podatkowa, op. cit.
} 


\section{Obciążenia przedsiębiorstw z tytułu podatków majątkowych}

Podatki majątkowe (przede wszystkim: podatek od nieruchomości, podatek od środków transportowych ${ }^{32}$ ) wpływają na sytuację finansową przedsiębiorstw dwukierunkowo. Przejawia się to w postaci efektów bezpośrednich, czyli we wpływie na obniżenie zysku brutto (podatki te obciążają koszty prowadzonej działalności), oraz efektów pośrednich, oznaczających ich wpływ na zmniejszenie podstawy opodatkowania w podatkach dochodowych (stanowią one koszty uzyskania przychodów). Wysokość podatków majątkowych jako kosztu uzyskania przychodu wpływa zatem na wynik przedsiębiorstwa. Podatki majątkowe, mając wpływ na zysk (w ujęciu podatkowym - dochód) przedsiębiorstwa i będąc składnikiem kosztów, determinują ostateczny wymiar podatków dochodowych. Oczywiście dla przedsiębiorstw ważny jest łączny efekt, będący wypadkową dwóch elementów, czyli obniżenia zysku oraz zmniejszenia podatku dochodowego. $W$ tej sytuacji korzyści z tytułu obniżenia podatku dochodowego nie rekompensują w pełni zmniejszenia wyniku finansowego przedsiębiorstw w związku z obciążeniem podatkami majątkowymi. Uwzględnienie tych podatków w bilansie podatkowym powoduje zatem częściowe tylko zrekompensowanie skutków obciążenia nimi bieżących kosztów działalności przedsiębiorstwa.

Wykorzystanie w działalności gospodarczej majątku nieruchomego wiąże się z koniecznością zapłaty podatku od nieruchomości: od gruntu, budynków oraz budowli związanych z prowadzeniem działalności gospodarczej. Wymiar podatku w przypadku gruntów oraz budynków jest stosunkowo prosty, ponieważ za podstawę opodatkowania przyjmuje się odpowiednio powierzchnię oraz powierzchnię użytkową. Natomiast dla budowli jest to wartość ustalona dla potrzeb amortyzacji podatkowej lub ich wartość rynkowa. Stawki są zróżnicowane i zależą od rodzaju nieruchomości (obiektu budowlanego) oraz sposobu jego wykorzystania. W 2019 r. maksymalne stawki wynoszą: dla gruntów 0,93 zł od $1 \mathrm{~m}^{2}$ powierzchni; dla budynków $23,47 \mathrm{zł} \mathrm{od} 1 \mathrm{~m}^{2}$ powierzchni użytkowej; dla budowli $2 \%$ ich wartości. Stawki podatku ustala rada gminy w drodze uchwały, z tym że nie mogą one przekroczyć górnej granicy. Rada gminy może również różnicować wysokość stawek dla poszczególnych rodzajów przedmiotów opodatkowania, a więc może wykorzystywać instrumenty wspierające rozwój przedsiębiorczości na swoim terenie. To istotny element, nie tylko w kontekście braku w przepisach polskiej ustawy o podatkach i opłatach lokalnych rozwiązań wspierających rozwój przedsiębiorstw. W aspekcie płynności finansowej odnotujmy, że elementem decydującym o terminie zapłaty podatku jest charakter podmiotu władającego nieruchomością. Osoby fizyczne wpłacają podatek $\mathrm{w}$ innej częstotliwości niż miesięczna (proporcjonalne raty w terminach do 15:

32 Zostały one uregulowane w ustawie z 12 stycznia 1992 r. o podatkach i opłatach lokalnych, t.j. Dz.U. 2018, poz. 1445, ze zm. 
marca, maja, września i listopada roku podatkowego). Dla mniejszych podmiotów, dysponujących substancją majątkową, ze względu na ich ograniczenia kapitałowe rozwiązanie to może mieć duże znaczenie.

Podatek od środków transportowych związany jest z posiadaniem i eksploatowaniem - wskazanych przez ustawodawcę - środków transportowych. Podstawą opodatkowania jest liczba środków transportowych stanowiących własność przedsiębiorcy lub na niego zarejestrowanych. Nie jest ona jednak jednolita, bowiem znaczenie ma rodzaj środka transportowego (samochód ciężarowy, ciągniki siodłowe i balastowe, przyczepy i naczepy, autobusy) i jego cechy (dopuszczalna masa całkowita, liczba osi, rodzaj zawieszenia, liczba miejsc do siedzenia). Wymienione czynniki wpływają na wysokość, silnie zróżnicowanych, stawek kwotowych podatku. Wysokość stawek podatku stosowanych w danej gminie określa rada gminy, z tym że stawki te muszą się zawierać w granicach stawek minimalnych ${ }^{33} \mathrm{i}$ maksymalnych. Funkcjonujące preferencje w podatku są znikome i świadczą raczej o tym, że ustawodawca zrezygnował z rozwiązań, dzięki którym preferowano by rozwój określonych rodzajów działalności gospodarczej. Jedynie w instytucji zwrotu podatku z tytułu transportu kombinowanego $^{34}$ (drogowo-kolejowy) można zauważyć przejawy stosowania funkcji stymulacyjnej.

\section{Obciążenia przedsiębiorstw z tytułu parapodatków}

Spośród parapodatkowych obciążeń przedsiębiorstw największe znaczenie mają składki na ubezpieczenia społeczne (ZUS), zdrowotne, na Fundusz Pracy (FP).

W składkach na ubezpieczenia społeczne podstawą ich wymiaru dla przedsiębiorcy jest zadeklarowana przez niego kwota, jednak nie niższa niż $60 \%$ prognozowanego przeciętnego wynagrodzenia miesięcznego. W 2019 r. minimalna podstawa naliczania składek wynosi 2859 zł. Przedsiębiorcy rozpoczynający działalność gospodarczą mogą skorzystać z preferencyjnych rozwiązań. Pierwsze dotyczy tzw. działalności nierejestrowanejej i polega na braku obowiązku odprowadzania jakichkolwiek składek ZUS zarówno społecznych, jak i zdrowotnych. Działalność taka nie podlega bowiem obowiązkowi rejestracyjnemu. Drugie - tzw. ulga na start, polega na zwolnieniu z opłacania składek na ubezpieczenia społeczne w okresie pierwszych 6 miesięcy prowadzenia działalności

${ }^{33}$ Minimalne stawki dotyczą wskazanych środków transportowych o dopuszczalnej masie całkowitej równej lub wyższej niż 12 ton.

${ }^{34}$ Zwrot podatku uzależniono od liczby jazd $\mathrm{z}$ ładunkiem lub bez ładunku. Obniżka podatku jest zróżnicowana i waha się od 25\% kwoty podatku (od 20 do 49 jazd) do $100 \%$ kwoty podatku (przy 100 jazdach i więcej).

${ }^{35}$ To taka działalność osoby fizycznej, z której przychód należny nie przekracza w żadnym miesiącu 50\% kwoty minimalnego wynagrodzenia i która w okresie ostatnich 60 miesięcy nie wykonywała działalności gospodarczej. 
gospodarczej. Warto dodać, że ulga jest prawem, a nie obowiązkiem. Ma to znaczenie dla przedsiębiorcy, bowiem niewpłacanie składek na ubezpieczenia społeczne w tym okresie oznacza brak świadczeń (np. zasiłku chorobowego), okres ulgi nie liczy się również do przyszłej emerytury.

Po upływie obowiązywania tej preferencji przedsiębiorca ma obowiązek regularnego opłacania składek. Może jednak skorzystać z kolejnej preferencji tzw. preferencyjnych składek na ubezpieczenia społeczne. W okresie pierwszych 24 miesięcy kalendarzowych od dnia rozpoczęcia działalności przedsiębiorcy mogą płacić składki od kwoty zadeklarowanej, nie niższej jednak niż 30\% kwoty minimalnego wynagrodzenia. W 2019 r. podstawa kształtuje się na poziomie $675 \mathrm{zl}$.

Nowym rozwiązaniem, funkcjonującym od 2019 r., jest jeszcze inna ulga tzw. mały ZUS (mała działalność gospodarcza). W przypadku przedsiębiorców osiągających relatywnie niskie dochody podstawa naliczania składek jest uzależniona od wielkości przychodów. Przychód z tytułu działalności gospodarczej w poprzednim roku kalendarzowym nie mógł przekroczyć trzydziestokrotności kwoty minimalnego wynagrodzenia obowiązującego $\mathrm{w}$ grudniu poprzedniego roku (w 2018 r. kwoty 63 tys. zł). Ulga obowiązuje przez 36 miesięcy w ciągu ostatnich 60 miesięcy kalendarzowych prowadzenia działalności gospodarczej.

Stopy procentowe składek na ubezpieczenia społeczne są stałe dla wszystkich, z wyjątkiem ubezpieczenia wypadkowego. Wysokość tej stawki podlega zróżnicowaniu ze względu na występujące ryzyko i rodzaj prowadzonej działalności gospodarczej. Składka ta w wysokości 1,67\% dotyczy przedsiębiorców niepodlegających wpisowi do rejestru REGON oraz zgłaszających nie więcej niż 9 ubezpieczonych. Wysokość pozostałych stóp procentowych wynosi: $19,52 \%$ dla emerytalnej, $8 \%$ dla rentowej oraz $2,45 \%$ dla chorobowej. Przedsiębiorca w 2019 r. płaci zatem miesięczne składki na ubezpieczenia społeczne w wysokości 904,60 zł. Natomiast przedsiębiorcy, u których podstawa wymiaru składek zależy od minimalnego wynagrodzenia, ponoszą miesięcznie wydatek w wysokości 213,57 zł.

Ponadto dochodzą składki na FP - w wysokości 2,45\% podstawy wymiaru (podstawa jak w przypadku ubezpieczeń społecznych), czyli w 2019 r. miesięcznie kwota 70,05 zł (przedsiębiorcy korzystający z preferencyjnego ZUS nie płacą składki na FP).

Dla składek na ubezpieczenia zdrowotne podstawą wymiaru jest zadeklarowana kwota, ale nie niższa niż 75\% przeciętnego miesięcznego wynagrodzenia $\mathrm{w}$ sektorze przedsiębiorstw w czwartym kwartale roku poprzedniego, włącznie z wypłatami z zysku. W 2019 r. podstawa ta wynosi 3803,56zł. Składka na ubezpieczenia zdrowotne wynosi 9\% podstawy wymiaru, przy czym część składki (7,75\% podstawy wymiaru) odliczana jest od podatku. W 2019 r. miesięczna składka z tytułu prowadzenia działalności gospodarczej wynosi więc 342,32 zł, z czego 294,78 zł można odliczyć od podatku. 
Przedsiębiorcy mogą także zawiesić wykonywanie działalności gospodarczej (art. 23 ust. 1 Prawa przedsiębiorców ${ }^{36}$ ), co oznacza nie tylko oszczędności z tytułu nieopłacania składek ubezpieczeniowych i zdrowotnej, ale także mniej obowiązków.

Spośród parapodatkowych obciążeń największy wpływ na koszty pracy mają niewątpliwie składki na ubezpieczenia społeczne. Uwzględnijmy więc ponadto wydatki przedsiębiorcy związane $\mathrm{z}$ zatrudnieniem pracownika na umowę o pracę. Wówczas kosztem dla przedsiębiorcy będą zarówno wynagrodzenie pracownika, jak i składki ZUS obciążające pracodawcę. Wynoszą one nieco ponad $20 \%$ wynagrodzenia brutto (9,76\% składka emerytalna, $6,5 \%$ składka rentowa, 1,67\% składka wypadkowa ${ }^{37}, 2,45 \%$ FP). Przyjmując więc, że przedsiębiorca zatrudnia pracownika na podstawie umowy o pracę w pełnym wymiarze godzin i ustala wynagrodzenie brutto w wysokości $2250 \mathrm{zl}$ (minimalne wynagrodzenie w 2019 r.), wówczas całkowity koszt zatrudnienia wynosi 2708,55 zł (2250 zł + 458,55 zł). Oczywiście, koszty przedsiębiorcy są $\mathrm{w}$ pewnym stopniu redukowane przez niższy podatek w związku z zaliczeniem także składek do kosztów uzyskania przychodu przy ustalaniu dochodu jako podstawy opodatkowania.

\section{Analiza danych empirycznych}

\section{Przeciętna kwota zapłaconego podatku dochodowego}

Obciążenie działalności gospodarczej wieloma tytułami prawnymi wymaga ponoszenia w ciągu roku podatkowego obowiązku zapłaty określonych kwot podatku przez przedsiębiorców. Są one wynikiem także odliczeń, zwolnień oraz ulg podatkowych. Występują również kwoty zwiększenia podatku. Ostateczny rezultat tych rozliczeń dla wybranych form rozliczeń podatkowych został przedstawiony w tabeli 1 .

Przeciętne, najniższe statystyczne obciążenie podatkowe dla przedsiębiorcy występuje przy karcie podatkowej, nieco wyższe przy ryczałcie od przychodów ewidencjonowanych. Obie formy ryczałtowe są jednak skierowane do ograniczonego kręgu podmiotowego podatników i niosą ryzyko - na co zwracano uwagę - konieczności zapłaty podatku niezależnie od osiągniętego przychodu (dochodu) nieuwzględniające bieżącej koniunktury i wyniku działalności przedsiębiorstwa. Przedsiębiorcy rozliczający się stawką liniową (składający zeznanie PIT-36L) płacą najwyższą przeciętną kwotę podatku.

36 Ustawa z 6 marca 2018 r. - Prawo przedsiębiorców, t.j. Dz.U. 2019 poz. 1292, ze zm.

37 Składka wypadkowa wynosi od 0,67-3,33\% podstawy wymiaru. Tu przyjęto rozwiązanie, o którym już wspomniano, oznaczające 50\% najwyższej stopy procentowej. 
Tabela 1. Przeciętna kwota zapłaconego podatku według formy rozliczenia podatku*

(w tys. zł)

\begin{tabular}{|c|c|c|c|}
\hline Rok & $\begin{array}{c}\text { Ryczałt od przychodów } \\
\text { ewidencjonowanych }\end{array}$ & Karta podatkowa & PIT-36L \\
\hline 2010 & 2,10 & b.d. & b.d. \\
\hline 2011 & 2,34 & 0,74 & 34,66 \\
\hline 2012 & 2,26 & 0,74 & 32,20 \\
\hline 2013 & 2,18 & 0,75 & 33,23 \\
\hline 2014 & 2,38 & 0,71 & 35,38 \\
\hline 2015 & 2,51 & 0,61 & 38,00 \\
\hline 2016 & 2,61 & 0,67 & 38,80 \\
\hline 2017 & 3,03 & 0,66 & 41,91 \\
\hline
\end{tabular}

*Ze względu na niedostateczne uszczegółowienia danych ministerialnych dotyczących opodatkowania przedsiębiorców prowadzących działalność gospodarczą podatkiem od osób fizycznych zawężono dane z tego tytułu tylko do danych budżetowych dotyczących rozliczeń przez formularz PIT-36L, którym rozliczają się podatnicy, osiągający dochody z pozarolniczej działalności gospodarczej lub działów specjalnych produkcji rolnej wg 19\% stawki podatku. Wybrane dane mogą zawierać część płaconą z tytułu najmu. Źródło: na podstawie danych Ministerstwa Finansów.

\section{Przeciętny przychód podatników rozliczających się ryczałtem ewidencjonowanym}

Przeciętny przychód podatników, którzy wybrali ryczałt od przychodów ewidencjonowanych, ma tendencję wzrostową (wykres 1). Corocznie ponad $90 \%$ wpływów podatkowych uzyskiwanych z tego tytułu wynika jedynie z działalności przedsiębiorstw obciążonych stawkami ryczałtu wymienionymi poniżej:

- $8,5 \%$ - dla przychodów osiąganych m.in. z działalności usługowej,

- 5,5\% - dla przychodów m.in. z działalności wytwórczej, robót budowlanych,

- 3,0\% - dla przychodów osiąganych m.in. z działalności handlowej.

Przedsiębiorcy wykonujący działalność gospodarczą objętą tymi stawkami osiągają z roku na rok coraz lepsze wyniki finansowe. Najbardziej efektywną działalnością jest działalność obłożona stawką 3,0\%, przy której wartość przeciętna przypadająca na podatnika wzrosła o 43\% w ciągu 7 lat. Jednakże są obostrzenia co do wyboru ryczałtu ewidencjonowanego, m.in. przychody z prowadzonej działalności nie mogą przekroczyć wartości 250 tys. euro, co ogranicza liczebność potencjalnych przedsiębiorców wybierających taki sposób opodatkowania. 
Wykres 1. Przeciętny przychód podatników rozliczających się ryczałtem od przychodów ewidencjonowanych w wybranych stawkach w stosunku do przychodu osiągniętego w 2010 r.

(w \%)

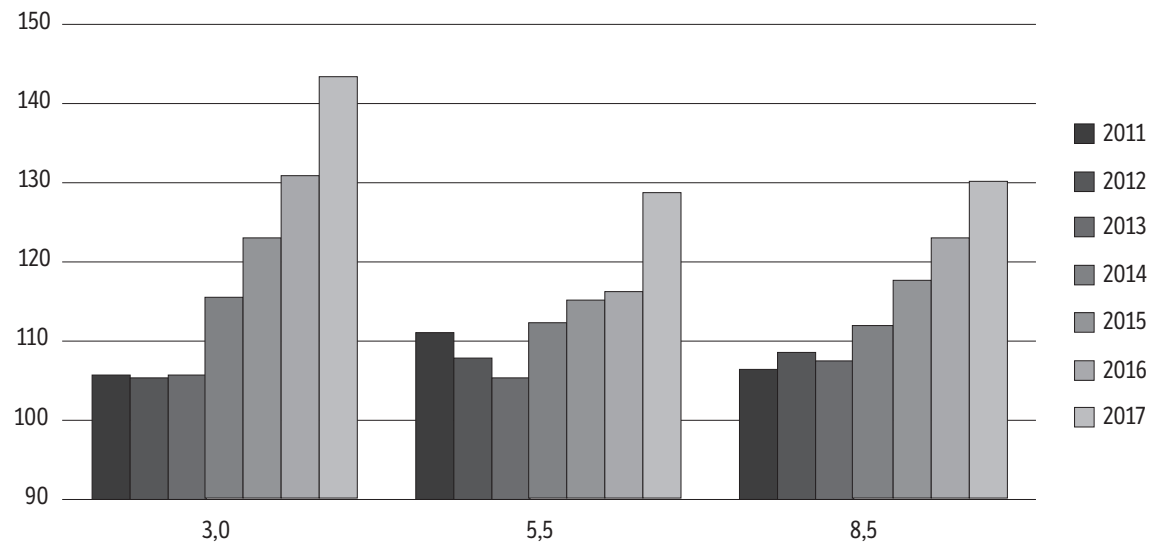

Źródło: na podstawie danych Ministerstwa Finansów.

\section{Stawka nominalna i efektywna ryczałtu ewidencjonowanego}

Przeciętna stawka nominalna ryczałtu od przychodów ewidencjonowanych kształtowała się w latach 2010-2017 w granicach 5,7-5,9\%. Jednakże faktyczna stawka ryczałtu (stawka efektywna), którą przeciętny przedsiębiorca rozliczający się ryczałtem uiszcza wobec budżetu, stanowiła wartość o ponad 2 punkty procentowe niższą (wykres 2). Różnica między stawką nominalną a efektywną wskazuje wielkość odliczeń wykorzystanych przez przedsiębiorców.

Wykres 2. Przeciętne nominalne i efektywne stawki ryczałtu od przychodów ewidencjonowanych z pozarolniczej działalności gospodarczej (w \%)

\begin{tabular}{|c|c|c|c|c|c|c|}
\hline 5,70 & 5,70 & 5,70 & 5,80 & 5,80 & 5,80 & 5,80 \\
\hline 3,60 & 3,70 & 3,60 & 3,60 & 3,60 & 3,60 & 3,60 \\
\hline
\end{tabular}

\begin{tabular}{|c|c|c|c|c|c|c|c|}
\hline 2010 & 2011 & 2012 & 2013 & 2014 & 2015 & 2016 & 2017 \\
\hline
\end{tabular}

Źródło: na podstawie danych Ministerstwa Finansów. 


\section{Rozliczenie strat z lat ubiegłych}

Rozliczenie strat $\mathrm{z}$ lat ubiegłych było w największym stopniu wykorzystywane przez podatników CIT (tabela 2). Podatnicy ci osiągnęli największą wartościowo korzyść z odliczenia strat od dochodu liczoną na jednego podatnika - przeciętnie ponad 324 tys. zł w $2015 \mathrm{r}$.

Tabela 2. Rozliczenie strat z lat ubiegłych

\begin{tabular}{|l|c|c|c|c|c|c|}
\hline Rok & $\begin{array}{c}\text { Liczba } \\
\text { podatników } \\
\text { CIT } \\
\text { odliczających } \\
\text { stratę }\end{array}$ & $\begin{array}{c}\text { Przeciętna } \\
\text { kwota } \\
\text { odliczeń strat } \\
\text { przy CIT } \\
\text { (w tys. zł) }\end{array}$ & $\begin{array}{c}\text { Liczba } \\
\text { podatników } \\
\text { płacących } \\
\text { ryczałt od } \\
\text { przychodów } \\
\text { ewidencjo- } \\
\text { nowanych } \\
\text { odliczających } \\
\text { stratę }\end{array}$ & $\begin{array}{c}\text { Przeciętna } \\
\text { kwota } \\
\text { odliczeń strat } \\
\text { przy ryczałcie } \\
\text { (w tys. zł) }\end{array}$ & $\begin{array}{c}\text { Liczba } \\
\text { podatników } \\
\text { PIT-36L } \\
\text { odliczających } \\
\text { stratę }\end{array}$ & $\begin{array}{c}\text { Przeciętna } \\
\text { kwota } \\
\text { odliczeń strat } \\
\text { przy PIT-36L } \\
\text { (w tys. zł) }\end{array}$ \\
\hline 2010 & 25511 & 396,21 & b.d. & b.d. & 21297 & 38,70 \\
\hline 2011 & 28720 & 418,59 & 1551 & 8,55 & 23832 & 41,02 \\
\hline 2012 & 29255 & 393,76 & 1636 & 4,85 & 23283 & 38,08 \\
\hline 2013 & 34153 & 367,00 & 1512 & 7,85 & 25841 & 43,14 \\
\hline 2014 & 36790 & 371,22 & 1536 & 7,57 & 26996 & 42,38 \\
\hline 2015 & 38813 & 324,80 & 1806 & 8,41 & 27414 & 43,35 \\
\hline 2016 & b.d. & b.d. & 1574 & 7,33 & 26262 & 42,45 \\
\hline 2017 & b.d. & b.d. & 1550 & 7,26 & 27993 & 47,95 \\
\hline
\end{tabular}

Źródło: na podstawie danych Ministerstwa Finansów.

Jednakże kwota przeciętnego odliczenia podatników CIT zmniejsza się. Podobna tendencja występuje przy odliczeniach strat przy ryczałcie. Wzrasta natomiast wielkość strat odliczanych przy PIT-36L, co pozwala domniemywać, że działalność gospodarcza opodatkowana tą formą jest coraz bardziej narażona na osiągnięcie strat. Wciąż jednak większą podatnością na straty charakteryzują się podatnicy CIT.

\section{Ulgi na innowacje}

Inną preferencją adresowaną do przedsiębiorców jest możliwość odliczenia od podstawy opodatkowania wydatków związanych z działalnością B+R. Do końca 2015 r. była to ulga na nabycie nowych technologii (później tylko na zasadzie praw nabytych), a od $2016 \mathrm{r}$. wprowadzono nowy tytuł odliczenia wspomagający rozwój innowacyjności w gospodarce - koszty kwalifikowane związane z działalnością badawczo-rozwojową. W tabeli 3 przedstawiono przeciętną kwotę odliczeń dla podatników podatku dochodowego od osób prawnych oraz fizycznych.

Przy porównaniu skali wykorzystania tej formy pomniejszenia dochodu do opodatkowania dostrzegalny jest gwałtowny spadek przeciętnej wartości. Nowa ulga dotycząca kosztów kwalifikowanych funkcjonuje jednak od niedawna. Być 
Tabela 3. Przeciętna kwota odliczeń z tytułu nabycia nowych technologii i działalności badawczo-rozwojowej w przedsiębiorstwach

(w tys. zł)

\begin{tabular}{|c|c|c|c|c|}
\hline Rok & Tytuł odliczenia & CIT & $\begin{array}{c}\text { PIT } \\
(18 \%, 32 \%)\end{array}$ & PIT-36L \\
\hline 2010 & \multirow[t]{6}{*}{ Nabycie nowych technologii } & 948 & 0,65 & - \\
\hline 2011 & & 2793 & 1,05 & - \\
\hline 2012 & & 4674 & 3,33 & - \\
\hline 2013 & & 4090 & 28,55 & - \\
\hline 2014 & & 3548 & 20,38 & - \\
\hline 2015 & & 4933 & 1,65 & - \\
\hline 2016 & \multirow{2}{*}{$\begin{array}{l}\text { Nabycie nowych technologii } \\
\text { (prawa nabyte) }\end{array}$} & 1135 & b.d. & - \\
\hline 2017 & & 148 & b.d. & - \\
\hline 2016 & \multirow{2}{*}{$\begin{array}{l}\text { Koszty kwalifikowane } \\
\text { (działalność badawczo-rozwojowa) }\end{array}$} & 751 & 4,06 & 43,64 \\
\hline 2017 & & 962 & 6,87 & 97,57 \\
\hline
\end{tabular}

Źródło: na podstawie danych Ministerstwa Finansów.

Tabela 4. Przeciętna strata lub dochód podatników rozliczających się przez CIT

\begin{tabular}{|c|c|c|c|c|}
\hline Rok & $\begin{array}{c}\text { Liczba podatników } \\
\text { CIT wykazujący stratę }\end{array}$ & $\begin{array}{c}\text { Przeciętna strata } \\
\text { (w tys. zł) }\end{array}$ & $\begin{array}{c}\text { Liczba podatników } \\
\text { CIT wykazujący } \\
\text { dochód }\end{array}$ & $\begin{array}{c}\text { Przeciętny dochód } \\
\text { (w tys. zł) }\end{array}$ \\
\hline 2010 & 97313 & 314 & 236773 & 741 \\
\hline 2011 & 98960 & 315 & 249907 & 804 \\
\hline 2012 & 109036 & 345 & 262329 & 721 \\
\hline 2013 & 112987 & 297 & 280836 & 701 \\
\hline 2014 & 119267 & 294 & 296900 & 693 \\
\hline 2015 & 126685 & 282 & 311059 & 714 \\
\hline 2016 & 142852 & 353 & 321376 & 707 \\
\hline 2017 & 148616 & 267 & 339246 & 893 \\
\hline
\end{tabular}

Źródło: na podstawie danych Ministerstwa Finansów.

może jest to sprzężone z wprowadzeniem preferencyjnej stawki podatkowej CIT (15\% w 2017 r.), ale na podstawie uzyskanych danych nie można tego stwierdzić.

Zestawione w tabeli 4 dane dotyczące wielkości strat i dochodów podatników CIT wskazują na spadek przeciętnej straty i wzrost przeciętnego dochodu. Malejąca przeciętna kwota strat odliczanych przy CIT może sugerować zmiany w zakresie strategii finansowej przedsiębiorstw nastawionych przeważnie na zmniejszenie wydatków na inwestycje w obszar B+R.

\section{Obowiązkowe obciążenia wyniku finansowego przedsiębiorstw}

Rozpatrując przedsiębiorstwa liczące ponad 10 pracowników, można dostrzec zwiększającą się liczbę takich przedsiębiorstw przy jednoczesnym wzroście ich wyniku netto (tabela 5). W ciągu 8 lat ten wynik wzrósł o 42\%, osiągając łącznie $149851 \mathrm{mln}$ zł dla całej populacji. Obciążenie wyniku finansowego zwiększało się z roku na rok, ale wartość obciążenia wobec wyniku netto i brutto od 2013 r. stanowi względnie stałą relację, odpowiednio ok. 15\% i 17\%, z tendencją rosnącą. 
Tabela 5. Obowiązkowe obciążenia wyniku finansowego przedsiębiorstw

\begin{tabular}{|c|c|c|c|c|c|}
\hline Rok & $\begin{array}{c}\text { Liczba } \\
\text { pracujących }\end{array}$ & Liczba jednostek & $\begin{array}{l}\text { Wynik brutto } \\
\text { (w mln zł) }\end{array}$ & $\begin{array}{l}\text { Obowiązkowe } \\
\text { obciążenia wyniku } \\
\text { finansowego } \\
\text { (w mln zł) }\end{array}$ & $\begin{array}{c}\text { Wynik netto } \\
\text { (w mln zł) }\end{array}$ \\
\hline \multirow{3}{*}{2010} & Razem & 47242 & 126349 & 21090 & 105259 \\
\hline & $10-49$ & 29717 & 18861 & 3047 & 15814 \\
\hline & $49<$ & 17525 & 107489 & 18043 & 89445 \\
\hline \multirow{3}{*}{2011} & Razem & 48736 & 134009 & 23749 & 110259 \\
\hline & $10-49$ & 31390 & 9122 & 2813 & 6309 \\
\hline & $49<$ & 17346 & 124887 & 20936 & 103950 \\
\hline \multirow{3}{*}{2012} & Razem & 49906 & 120631 & 20560 & 100071 \\
\hline & $10-49$ & 32312 & 21259 & 3305 & 17954 \\
\hline & $49<$ & 17594 & 99372 & 17255 & 82117 \\
\hline \multirow{3}{*}{2013} & Razem & 49833 & 126910 & 18745 & 108165 \\
\hline & $10-49$ & 32614 & 18797 & 2739 & 16058 \\
\hline & $49<$ & 17219 & 108114 & 16006 & 92108 \\
\hline \multirow{3}{*}{2014} & Razem & 50734 & 127822 & 18614 & 109208 \\
\hline & $10-49$ & 33736 & 22137 & 3087 & 19050 \\
\hline & $49<$ & 16998 & 105686 & 15527 & 90159 \\
\hline \multirow{3}{*}{2015} & Razem & 50786 & 133488 & 20046 & 113442 \\
\hline & $10-49$ & 33611 & 25273 & 3372 & 21901 \\
\hline & $49<$ & 17175 & 108215 & 16674 & 91541 \\
\hline \multirow{3}{*}{2016} & Razem & 51129 & 157425 & 23761 & 133664 \\
\hline & $10-49$ & 33664 & 26007 & 3406 & 22601 \\
\hline & $49<$ & 17465 & 131418 & 20355 & 111063 \\
\hline \multirow{3}{*}{2017} & Razem & 50385 & 177282 & 27431 & 149851 \\
\hline & $10-49$ & 32553 & 27208 & 3753 & 23455 \\
\hline & $49<$ & 17832 & 150074 & 23678 & 126396 \\
\hline
\end{tabular}

Źródło: na podstawie danych GUS.

Nieznacznie zwiększa się populacja średnich i dużych przedsiębiorstw. Od 2016 r. następuje wzrost ich wyniku netto i brutto, wobec obniżenia występującego w latach 2012-2015.

Populacja małych przedsiębiorstw nie ma stałej tendencji w zmianie liczebności. Interesujący jest spadek wyniku brutto małych przedsiębiorstw w 2011 r., który można próbować przypisać opóźnionym rezultatom kryzysu finansowego z przełomu 2007/2008. Nie nastąpiła jednak wówczas jednocześnie obniżka obciążeń wyniku finansowego w ujęciu wartościowym (zob. tabela 6). Od 2014 r. małe przedsiębiorstwa weszły na ścieżkę stałego wzrostu wyniku finansowego i jednocześnie wzrostu obciążeń fiskalnych. 
Tabela 6. Udział wybranych kosztów rodzajowych w kosztach ogółem przedsiębiorstw

\begin{tabular}{|c|c|c|c|c|c|}
\hline Rok & $\begin{array}{c}\text { Liczba } \\
\text { pracujących }\end{array}$ & $\begin{array}{l}\text { Koszty ogółem } \\
\text { (w mln zł) }\end{array}$ & $\begin{array}{l}\text { Udział podatków } \\
\text { i opłat (bez } \\
\text { akcyzy) } \\
\text { (w \%) }\end{array}$ & $\begin{array}{c}\text { Udział } \\
\text { ubezpieczeń } \\
\text { społecznych } \\
\text { i innych świadczeń } \\
(w \%)\end{array}$ & $\begin{array}{c}\text { Udział } \\
\text { wynagrodzeń } \\
\text { (w \%) }\end{array}$ \\
\hline \multirow{3}{*}{2010} & Razem & 1393300 & 1,73 & 3,25 & 14,83 \\
\hline & $10-49$ & 154795 & 1,94 & 3,22 & 17,98 \\
\hline & $49<$ & 1238504 & 1,71 & 3,25 & 14,44 \\
\hline \multirow{3}{*}{2011} & Razem & 1584443 & 1,74 & 3,05 & 13,99 \\
\hline & $10-49$ & 179374 & 1,74 & 3,03 & 17,14 \\
\hline & $49<$ & 1405068 & 1,73 & 3,05 & 13,59 \\
\hline \multirow{3}{*}{2012} & Razem & 1660581 & 1,71 & 3,25 & 13,91 \\
\hline & $10-49$ & 187669 & 1,80 & 3,24 & 17,00 \\
\hline & $49<$ & 1472912 & 1,70 & 3,25 & 13,52 \\
\hline \multirow{3}{*}{2013} & Razem & 1663998 & 1,84 & 3,29 & 14,21 \\
\hline & $10-49$ & 193070 & 1,85 & 3,24 & 16,93 \\
\hline & $49<$ & 1470928 & 1,84 & 3,30 & 13,85 \\
\hline \multirow{3}{*}{2014} & Razem & 1717820 & 1,79 & 3,38 & 14,54 \\
\hline & $10-49$ & 207086 & 1,83 & 3,21 & 16,83 \\
\hline & $49<$ & 1510734 & 1,79 & 3,40 & 14,22 \\
\hline \multirow{3}{*}{2015} & Razem & 1786301 & 1,87 & 3,34 & 14,72 \\
\hline & $10-49$ & 218926 & 1,81 & 3,23 & 16,83 \\
\hline & $49<$ & 1567375 & 1,88 & 3,35 & 14,43 \\
\hline \multirow{3}{*}{2016} & Razem & 1835719 & 1,94 & 3,45 & 15,26 \\
\hline & $10-49$ & 221129 & 1,81 & 3,38 & 17,46 \\
\hline & $49<$ & 1614589 & 1,96 & 3,46 & 14,95 \\
\hline \multirow{3}{*}{2017} & Razem & 1990096 & 1,86 & 3,49 & 15,32 \\
\hline & $10-49$ & 219536 & 1,81 & 3,46 & 17,83 \\
\hline & $49<$ & 1770560 & 1,87 & 3,49 & 15,01 \\
\hline
\end{tabular}

Źródło: na podstawie danych GUS.

\section{Udział wybranych kategorii kosztów w kosztach ogółem}

W zestawieniu rodzajowym kosztów przedsiębiorstw dostrzegalny jest stały wzrost udziału kosztów podatkowych, ubezpieczeń społecznych i wynagrodzeń w kosztach ogółem. Aczkolwiek występuje wzrost wartości kosztów i równocześnie wzrost wyniku netto przedsiębiorstw zatrudniających powyżej 10 pracowników, to skumulowana wartość obciążeń fiskalnych państwa realnie się zwiększa.

\section{Zakres wykorzystania rozliczenia kwartalnego i kasowego w podatku VAT}

Mali podatnicy chętniej wybierają kwartalną metodę rozliczania niż metodę kasową (wykres 3). Spośród małych podatników, którzy odeszli od zasad ogólnych na rzecz jednego z dwóch instrumentów opóźniania płatności VAT, było to corocznie ok. $95 \%$ populacji. 


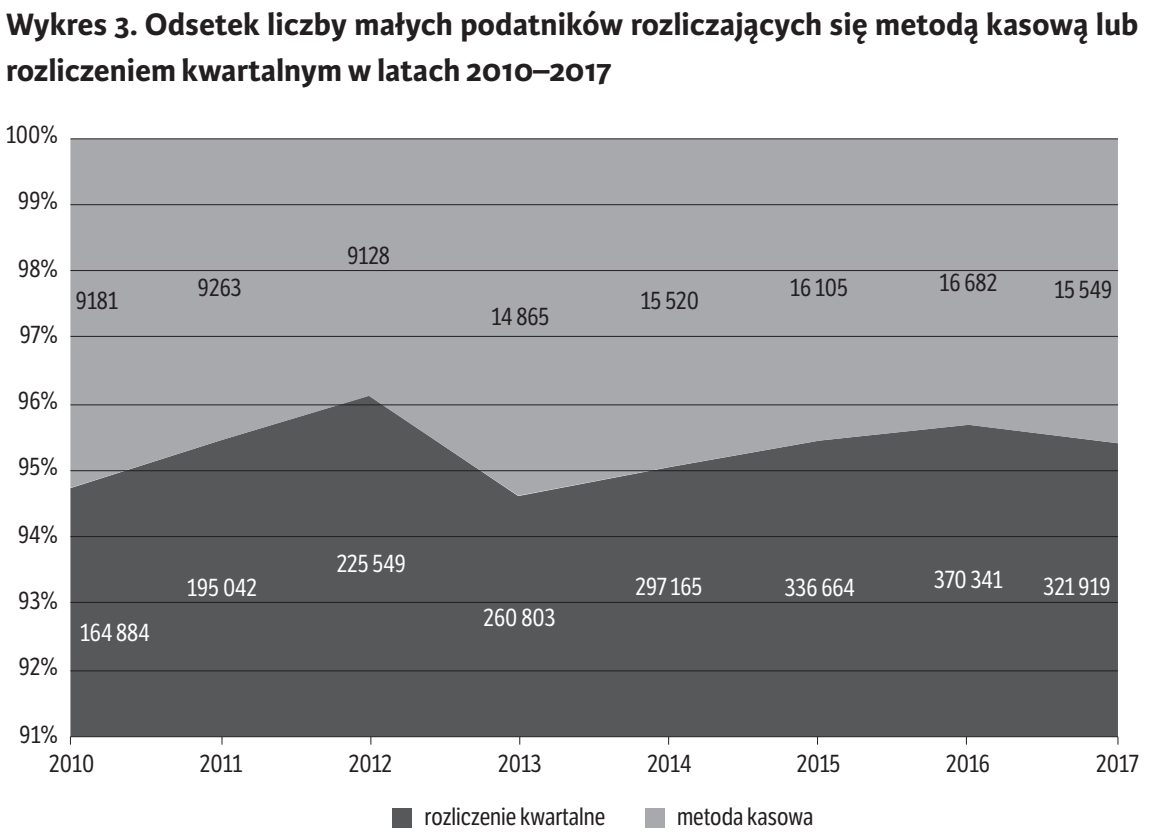

Źródło: na podstawie danych Ministerstwa Finansów.

\section{Podsumowanie}

Na podstawie przeprowadzonych rozważań, a także przytoczonych danych, można stwierdzić, że większość podatków i parapodatków powoduje istotne skutki dla przedsiębiorstw. Do głównych obszarów ich oddziaływania na gospodarkę finansową przedsiębiorstw można zaliczyć:

- bieżącą działalność operacyjną, czyli wpływ na ceny towarów i usług, możliwości zaopatrzenia i zbytu, płynność finansową,

- działalność inwestycyjną, czyli ograniczenie zdolności przedsiębiorstwa do rozwoju przez zmniejszanie nadwyżki finansowej lub jako źródło pozytywnych bodźców wkomponowanych w podatki zachęcające do podejmowania decyzji inwestycyjnych,

- działalność finansową, czyli kształtowanie struktury kapitałowej; regulacje dotyczące traktowania odsetek od długu (tarcza podatkowa) mogą wpływać na jego udział w pasywach przedsiębiorstwa.

Strategie przedsiębiorstw mogą uwzględniać mechanizmy obniżające obciążenia fiskalne. Są to różnego rodzaju zwolnienia, ulgi oraz ułatwienia w prowadzeniu działalności gospodarczej (np. mały podatnik, „mały ZUS”). Pomocą państwa jest również umożliwienie rozliczania strat w kolejnych latach, co jest 
aktywnym instrumentem dzielenia się ryzykiem rozwojowym przedsiębiorstw z budżetem państwa. Do rozwiązania pozostaje wciąż kwestia eliminacji dualizmu w opodatkowaniu dochodów spółek handlowych.

Są również inne rozwiązania prawne mające wspierać prowadzenie działalności gospodarczej, ale mogące mieć odwrotny skutek. Aczkolwiek ryczałtowe formy rozliczania podatku dochodowego dają korzyść przedsiębiorcom z uwagi na zwykle niższe stawki niż stawka w opodatkowaniu na zasadach ogólnych, to przy mniejszej skali mogą w istocie stanowić wyższą kwotę podatku należnego. Przedsiębiorcy płacący ryczałt od przychodów ewidencjonowanych czy rozliczający się kartą podatkową nie mogą ponadto korzystać z preferencji podatkowych w takim samym stopniu jak przedsiębiorcy opodatkowani na zasadach ogólnych.

Dla podatku VAT, który nie jest neutralny dla działalności przedsiębiorstw, są stosowane m.in. różne stawki preferencyjne, mechanizmy opóźnionej płatności podatku należnego, podzielona płatność (split payment) czy odliczenia od podatku należnego. Przy prowadzonej działalności trzeba mieć także na względzie podatki majątkowe, które w niektórych branżach mają istotne znaczenie, np. podatek od środków transportowych w branży TSL (Transport-Spedycja-Logistyka), oraz pozostałe tytuły podatkowe i parapodatkowe, w tym różnego rodzaju opłaty.

Przedsiębiorcy w badanym okresie osiągali coraz lepsze wyniki finansowe, ponosząc jednocześnie coraz wyższe obciążenia fiskalne. Zwiększał się również udział podatków majątkowych czy środków płaconych na ubezpieczenia społeczne w kosztach ogółem przedsiębiorstw niefinansowych zatrudniających 10 i więcej pracowników, co można rozpatrywać jako trend podkreślający rozwój gospodarczy. Wzrost liczby przedsiębiorstw niefinansowych oraz zmniejszenie się zbiorowości tych, które ponosiły stratę, wraz z realnym spadkiem wartości ich przeciętnej straty, jest pozytywnym zjawiskiem.

Natomiast zakres regulacji prawnych dotyczących opodatkowania działalności gospodarczej jest bardzo szeroki. Liczne przepisy odsyłające występujące w aktach prawnych, obok ryzyka rynkowego, dodatkowo utrudniają przedsiębiorcom dokonanie najkorzystniejszego wyboru formy opodatkowania. Utrudnienia dotyczą również podatników, którzy mieli skorzystać z możliwości prowadzenia uproszczonych rozliczeń. Można mieć jednak nadzieję na zweryfikowanie systemu podatkowego przez ustawodawcę i wprowadzenie przez niego m.in. zmian ujednolicających prawo bilansowe i podatkowe.

\section{Bibliografia}

Felis P., Obciążenie pozarolniczej działalności gospodarczej zryczałtowanym podatkiem od przychodów - stan obecny i perspektywy zmian, „Studia i Prace Kolegium Zarządzania i Finansów SGH” 2014, nr 137. 
Felis P., Ocena funkcjonowania podatków od dochodów osób fizycznych oraz osób prawnych w Polsce, „Studia BAS” 2018, nr 2(54) [Wybrane zagadnienia reformy opodatkowania dochodów osób fizycznych i prawnych w Polsce, red. J. Kulicki].

Felis P., Opodatkowanie wedtug zasad ogólnych, liniowe czy ryczałtowe - dylematy wyboru małych i średnich przedsiębiorstw [w:] Finanse przedsiębiorstwa, red. P. Karpuś, Wydawnictwo Uniwersytetu Marii Curie-Skłodowskiej, Lublin 2006.

Felis P., Wybrane rozwiązania opodatkowania matych przedsiębiorstw - ocena i proponowane kierunki zmian, „Studia BAS” 2014, nr 1(37) [Rozwój przedsiębiorczości oraz sektora małych $i$ średnich przedsiębiorstw, red. G. Gołębiowski].

Felis P., Szlęzak-Matusewicz J., Optymalizacja podatkowa a termin płatności podatku [w:] Eseje o finansach, red. J. Ostaszewski, P. Felis, J. Szlęzak-Matusewicz, Oficyna Wydawnicza SGH, Warszawa 2018.

Felis P., Jamroży M., Szlęzak-Matusewicz J., Podatki i składki w działalności przedsiębiorców, Difin, Warszawa 2019.

Flotyńska A., Alternatywne konstrukcje podatku od dochodów przedsiębiorstw, „Prace Naukowe Uniwersytetu Ekonomicznego we Wrocławiu” 2011, nr 172 [Finanse nowe wyzwania teorii i praktyki. Finanse przedsiębiorstw, red. S. Wrzosek].

Grądalski F., Teoretyczne aspekty reformowania systemu podatkowego - zarys modelu referencyjnego dla Polski [w:] O nowy ład podatkowy w Polsce, red. J. Ostaszewski, Oficyna Wydawnicza SGH, Warszawa 2007.

Grądalski F., Teoretyczne aspekty racjonalizacji systemu podatkowego [w:] Dorobek ekonomii, finansów i nauk o zarzadzaniu oraz jego praktyczne wykorzystanie na przełomie XX i XXI wieku, red. R. Bartkowiak, J. Ostaszewski, Oficyna Wydawnicza SGH, Warszawa 2012.

Ickiewicz J., Obciążenia fiskalne przedsiębiorstw, PWE, Warszawa 2009.

Iwin-Garzyńska J., System amortyzacji podatkowej w kontekście idei wspólnej skonsolidowanej podstawy opodatkowania, „Prace Naukowe Uniwersytetu Ekonomicznego we Wrocławiu" 2011, nr 172 [Finanse - nowe wyzwania teorii i praktyki. Finanse przedsiębiorstw, red. S. Wrzosek].

Jamroży M., Podatkowe zachęty inwestycyjne dla przedsiębiorców, „Prace Naukowe Uniwersytetu Ekonomicznego we Wrocławiu” 2011, nr 172 [Finanse - nowe wyzwania teorii i praktyki. Finanse przedsiębiorstw, red. S. Wrzosek].

Jamroży M., Dochody z działalności gospodarczej - analiza stanu obecnego i możliwe kierunki zmian, „Studia BAS” 2018, nr 2(54) [Wybrane zagadnienia reformy opodatkowania dochodów osób fizycznych i prawnych w Polsce, red. J. Kulicki].

Kluzek M., Charakter podatku dochodowego od osób fizycznych w Polsce [w:] O nowy ład podatkowy w Polsce, red. J. Ostaszewski, Oficyna Wydawnicza SGH, Warszawa 2007.

Kotlarek N., Ulga $z$ tytułu nowych technologii - mankamenty konstrukcji i propozycje modyfikacji, „Annales Universitatis Mariae Curie-Skłodowska, Sectio H Oeconomia” 2016, Vol. L, nr 1.

Kulicki J., Reforma opodatkowania dochodów [w:] Dylematy reformy systemu podatkowego w Polsce, red. H. Dzwonkowski, J. Kulicki, Wydawnictwo Sejmowe, Warszawa 2016. 
Olchowicz I., Jamroży M., Rachunkowość podatkowa. Analiza w zakresie podatku dochodowego od osób prawnych, Difin, Warszawa 2018.

Russel P., Leasing [w:] Finansowanie przedsiębiorstwa. Ujęcie teoretyczno-praktyczne, red. J. Szlęzak-Matusewicz, P. Felis, Wolters Kluwer, Warszawa 2014.

Szlęzak-Matusewicz J., Models of Tax Incentives for R\&D Activities of Enterprises in European Union Countries, „Copernican Journal of Finance \& Accounting” 2014, vol. 3, nr 1, http://dx.doi.org/10.12775/CJFA.2014.012.

Szlęzak-Matusewicz J., Odwrotne obciążenie VAT jako mechanizm przeciwdziałający oszustwom podatkowym, „Zeszyty Naukowe Uniwersytetu Szczecińskiego. Finanse, Rynki Finansowe, Ubezpieczenia” 2015, t. 1, nr 76 [Opodatkowanie przedsiębiorstw, red. J. Iwin-Garzyńska].

Szlęzak-Matusewicz J., Wybrane instrumenty optymalizacji podatkowej w mikroprzedsiębiorstwach - ocena i perspektywy zmian „Studia BAS” 2019, nr 2(58) [Uwarunkowania prowadzenia działalności gospodarczej w Polsce, red. A. Grycuk, P. Russel].

\section{Akty prawne}

Ustawa z 12 stycznia 1992 r. o podatkach i opłatach lokalnych, t.j. Dz.U. 2018, poz. 1445, ze $\mathrm{zm}$.

Ustawa z 26 lipca 1991 r. o podatku dochodowym od osób fizycznych, t.j. Dz.U. 2018, poz. 1509 , ze zm.

Ustawa z 15 lutego 1992 r. o podatku dochodowym od osób prawnych, t.j. Dz.U. 2018, poz. 1036, ze zm.

Ustawa z 20 listopada 1998 r. o zryczałtowanym podatku dochodowym od niektórych przychodów osiąganych przez osoby fizyczne, t.j. Dz.U. 2019, poz. 43.

Ustawa z 11 marca 2004 r. o podatku od towarów i usług, t.j. Dz.U. 2018, poz. 2174, ze zm.

Ustawa z 6 marca 2018 r. - Prawo przedsiębiorców, t.j. Dz.U. 2019 poz. 1292, ze zm. 